\title{
Does women's intra-household bargaining power have effect on child welfare? Evidence from farm households in Ogun state, Nigeria
}

\author{
Chioma Patricia ADEKUNLE ${ }^{1}$, Augustine Adebayo KUTU²,3, David Alaba ALORI ${ }^{4}$ \\ Received June 06, 2020; accepted March 03, 2021. \\ Delo je prispelo 06. junija 2020, sprejeto 03. marca 2021.
}

\begin{abstract}
Does women's intra-household bargaining power have effect on child welfare? Evidence from farm households in Ogun state, Nigeria

Abstract: This study examines whether greater women's household bargaining power is associated with the improvement in children's welfare in Ogun State, Nigeria. Using data from 320 farm households with a Logit regression model, the study revealed that $31.86 \%$ of children under-five years of age were stunted, $32 \%$ were underweight and $16.2 \%$ were wasted. Children growing up healthy were $62 \%$, implying that one third of under-five children in the study area still experience nutrition deficiency. About $3.33 \%$ and $1.05 \%$ children simultaneously experienced stunting and wasting together, which perhaps suggests a harsh deprivation environment. In addition, $63.33 \%$ of women in the study area had low bargaining power implying that they lack control over important decisions in their households. Women who enjoy decision-making power in their households, particularly with large purchasing power, are associated with having children with better height-for-age, mass-for-age, and mass-for-height ratios. Women's inequality as relates to intra-household bargaining power negatively affects children's welfare and leads to chronic malnutrition. As a policy recommendation, it is therefore, important to enhance women's status, which, with time will lead to more investment in their children's education, health, and overall welfare.

Key words: bargaining power; child welfare; mass index; Ogun state
\end{abstract}

Ali ima enakopravnost žensk v gospodinstvih vpliv na dobrobit otrok? Primeri iz kmečkih gospodinjstev iz države Ogun, Nigerija

Izvleček: V raziskavi je bilo preučevano, kako je enakopravnost žensk $\mathrm{v}$ gospodinjstvih povezana $\mathrm{z}$ izbolšanjem dobrobiti otrok, v državi Ogun, Nigerija. Z regresijskim logit modelom so bili obdelani podatki iz 320 kmečkih gospodinjstev. Raziskava je odkrila, da je bilo 31,86 \% otrok, v starosti pod pet let, zaostalih v razvoju, $32 \%$ jih je imelo premajhno maso in $16,2 \%$ jih je bilo podhranjenih in bolnih. Otrok, ki so doraščali zdravo je bilo $62 \%$, kar kaže na to, da so trije od petih otrok še vedno podhranjeni. Okrog 3,33\% in 1,05\% otrok se hkrati sooča z zaostankom v razvoju in podhranjenostjo, kar kaže na zelo nevzpodbudno okolje za razvoj otrok. Dodatno ima na preučevanem območju 63,33 \% žena majhno enakopravnost, kar kaže na pomankljivost njihovega odločanja o pomembnih zadevah v gospodinjstvih. Žene, ki imajo večjo moč odločanja $\mathrm{v}$ gospodinjstvih, še posebej tiste $\mathrm{z}$ večjo kupno močjo, imajo otroke, ki so višji glede na njihovo starost, močnejši in $z$ večjim razmerjem med maso in višino. Ženska neenakopravnost je povezana $\mathrm{z}$ njihovo neenakopravnostjo $\mathrm{v}$ gospodinjstvu, kar vpliva negativno na dobrobit otrok in vodi h kronični podhranjenosti. Priporočilo bi torej bilo, da je pomembno izboljšati položaj žena, kar bi s časom vodilo v več vlaganja v izobraževanje njihovih otrok, njihovega zdravja in v splošno izboljšanje stanja.

Ključne besede: enakopravnost; dobrobit otrok; masni indeks; država Ogun

Federal University of Agriculture, Department of Agricultural Economics and Farm management, Abeokuta, Nigeria

2 Federal University of Technology, Department of Agricultural Economics \& Extension, Minna, Nigeria

3 Corresponding author, e-mail: kutuA@ukzn.ac.za

4 University of KwaZulu-Natal, School of Accounting, Economics \& Finance, South Africa 


\section{INTRODUCTION}

Globally, the significance of women's empowerment in intra-household decision-making on household welfare has been a topical issue and debate among scholars. The debate centres on the need to enhance women's bargaining power and increase their participation in intrahousehold decision-making (Grown et al., 2005; Malhotra and Schuler, 2005). This subject is also captured in the Millennium Development Goals (MDGs) and the Sustainable Development Goals (SDGs) in order to achieve international development. The need to enhance women's empowerment and achieve economic growth also led to the formation of the World Bank's Gender Action Plan in 2006 (Zuckerman, 2007). Policymakers and development practitioners are of the opinion that women's empowerment is a necessity for societal development (Pratley, P. (2016). Based on this, an empirical research study in this nature is essential in order to be able to suggest to policymakers an effective policy to empower women both in the rural and urban areas for the purpose of achieving desired outcome of empowering women and promote their bargaining power in all economic fronts. It is important to note that lack of women's empowerment manifests in various ways, including in the labour market (increase unemployment), increase poverty and limited economic opportunities (Guvuriro and Booysen, 2019). In line with the need for women's empowerment, Yusof and Duasa (2010) and Doepke and Tertt (2014) revealed that women's empowerment can influence the allocation of resources including those that concern children and the one that relates to national development. This study finds that women remain economically disadvantaged in Nigeria when compared to their men counterparts. They are also disadvantaged in the intra-household decisionmaking power and are sometimes prevented from actively participate in cash-based work or labour market. This development accounts for the significance and motivation of this study, especially on the need to examine whether greater women's household bargaining power or empowerment will lead to the improvement in children's welfare in Nigeria.

According to Duflo (2000), there is a correlation between women's greater involvement in household decision-making and the allocation of spending in the family and among farm households, which benefit children. Duflo revealed that an increase in the women's decision-making power in the family would positively affect the expenditure allocation and overall children's wellbeing. This means that as the share of household income controlled by women increases, the welfare of the children is enhanced (World Bank, 2011). This is because an improvement in women's intra-household bargaining power and resources allocation lead to improved welfare outcomes of children (Wang, 2014).

According to the data released by UNICEF/WHO/ World Bank Group (2017), about 151 million of children under-five years suffer from malnutrition and 67 million were wasted globally in 2017 due to lack of women's empowerment. Studies have revealed that among the public health problems that resulted from lack of women's empowerment, malnutrition remains the highest among children in developing countries including Nigeria. Malnutrition affects the mental reasoning and physical development of children, increases the danger of infections and contributes to the child's illness and death (Pelletier and Frongillo, 2003). According to De Onis and Blössner (2003), stunting, wasting and underweight are the three major symptoms of a child's malnutrition. Stunting and wasting are an indication of chronic and acute malnutrition while underweight is a combination of both acute and chronic malnutrition (De Onis and Blössner 2003). All these problems and symptoms are because of lack of women's empowerment.

Various studies have shown that malnutrition contributes to the global burden of diseases. According to Liu et al. (2015), malnutrition accounts for $50 \%$ of all the global death rate among children under the age of five. The WHO (2016) also revealed that about 99 million of under-five year's children were either stunted, wasted or underweight globally while approximately 6 million children were stunting and wasting at the same time (Khara et al., 2018). Based on these figures, $55 \%$ of all stunted children were from Asia and $39 \%$ from Africa, while $69 \%$ of the stunting and wasting children were from Asia and $27 \%$ from Africa (UNICEF/WHO/World Bank Group, 2017) since women are lagging behind in terms of empowerment and involvement in households' decision-making.

In Nigeria, and especially among farm households, malnutrition is one of the most important factors that contribute to child mortality among under-five year's children. This occurs most among the farm households. According to UNICEF/WHO/World Bank (2017), mortality rates of about 128 deaths per 1000 births were recorded in 2017 while $37 \%$ of under-five children are stunted. Because of deficiency in women's empowerment and poor intra-households decision-making power, there is also the problem of maternal nutrition in which $11 \%$ and $25 \%$ prevalence of undernutrition and overweight/ obesity were recorded among women (National Population Commission and ICF International, 2014). This problem is more prevalent among farm households and as a result, children in rural areas are more likely to be stunted than those in urban areas (Herrador et al., 2014). It is against this view and background that this study 
seeks to examine whether greater women's household bargaining power is associated with the improvement in children's welfare using farm households in Ogun State as a case study. This study has meaningful implications for policy and contributes to the growing literature, which finds evidence supporting increased female bargaining power as a method to promote equality and improve child health outcomes. The rest of the article is as follows. The next section presents the empirical review of the literature. Section 3 presents the methodology employed in analyzing the research data. Section 4 contains the women's bargaining power and the questions that were contained in the questionnaire. Section 5 presents the results and discussion and section 6 concludes the study.

Many studies have established strong evidence of women's empowerment and higher intra-households decision-making power to translate into improved child wellbeing and societal development. For example, Gokhale et al. (2004) and Chen and Li (2009) show a strong link between women's education, decision-making and child survival or better living condition. AngelUrdinola and Wodon (2010) also revealed that women's earning and income generation contribute to women's empowerment and intra-households' decision-making. According to Urdinola and Wodon, wage gap is a sign of discrimination against women and this can hinder children's access to education, healthcare and other socialeconomic wellbeing.

Richards et al. (2013) carried out a study on gendered intra-household bargaining as a social determinant of child health and nutrition in the low and middleincome countries. They revealed that "intra-household bargaining power operates through inter-linked mechanisms that shape how resources are channelled to children in terms of nutrition and health inputs which lead to better child health and nutrition outcomes". Tolhurst et al. (2008) advocated a gender transformatory approach, which aims to promote women's empowerment and intra-household decision-making power needed in order to achieve gender relationships and quality wellbeing for the children.

Behrman and Skoufias (2006) highlighted the significance of income in achieving women's empowerment and greater intra-households decision-making. Based on their view, income in the hands of women will lead to a complete income pooling in the households and heighten the development of the entire family. Gummerson and Schneider (2013) supported this view and revealed that women are the more responsible managers of financial resources in the family. This is also in line with Behrman and Skoufias (2006) who stated that "policies targeted towards women can generate immediate consequences by either improving a women's voice in the household and/ or contributing to an improvement in human capital investments in children".

Expanding on the link between improved women's bargaining power and resource allocation, Doss (2013) revealed that there is a sufficient evidence to support the view that women's bargaining power does affect resource allocation and developmental outcomes. This means that there is a link between women's empowerment or bargaining power and the development of the society. Invariably, there is a link between the relative decisionmaking power at the household level and greater expansion of the development of the society. Martínez (2013) shared similar view and indicated that increased women's bargaining power would promote equality and improve child welfare. While carrying out a study of Women's intra-household bargaining power and child welfare outcomes, Saaka (2018) also revealed that women's empowerment is associated with benefits for women and their children.

However, despite the numerous studies on the women's intra-household bargaining power and children's welfare outcomes around the world, there is scanty research on the subject in Nigeria. Realizing this empirical gap in the literature, this study is undertaken to contribute to the debate on whether greater women's household bargaining power is associated with the improvement in children's welfare in Nigeria. It is expected that the findings of the study will help enlighten policymakers on the wisdom of formulating policies that enhance women's empowerment and increase their bargaining power within the household as well as increase spending on long-term durable goods (education and nutrition of children).

\section{METHODOLOGY}

\subsection{STUDY AREA}

The study area is Ogun State in South West Nigeria. The state was created in February, 1976 with Abeokuta as the capital. It has a land of approximately 1.7 million hectares and occupies about $1.9 \%$ of Nigeria's total land and about $2.5 \%$ of the country's population. It has 20 local government areas spread across the four main agricultural zones of the state- Egba, Ijebu, Remo, and Yewa/ Awori. The state shares an international boundary with Benin Republic to the west and Oyo state to the north, Lagos state to the south, and Ondo state to the east. In addition, the state has a population of 3.7 million based on 2006 national population census. There are two distinct seasons in the state namely, the rainy season and the 
dry season and in terms of farming activities, the state is well known for livestock and cocoa production.

Fasina et al. (2020) revealed that the death of newborn babies resulting from malnutrition and neonatal mortality is very high in the state. There is poor access to quality education and health care facilities especially among the rural farm households. Poor care-seeking behaviour of families due to unemployment and poor salaries are high in the area. Ogunlesi and Ogunlesi (2012) also revealed that low health care education and the use of home remedies are the common living status of farm households in the study area.

\subsection{STUDY DATA AND METHODS OF DATA COL- LECTION}

The data for the study were collected through a well-structured questionnaire and interview from the rural farmers. Data were collected on the socio-economic characteristics such as age, age at marriage, number of years in marriage, gender, marital status, educational status, and other variables of mother and child (such as employment status, monthly income, land ownership, livestock ownership and access to credit). The mass and height of children were collected through the anthropometric measurement procedures and counter-checked using their vaccination cards.

\subsection{SAMPLE AND SAMPLING TECHNIQUE}

This study employed the multistage sampling technique; at stage one, two agricultural zones of Ijebu and Ilaro were selected out of the four zones in the state. At stage two, $50 \%$ of the blocks were selected from each zone. This gives three blocks for Ijebu and two blocks for Ilaro and translates to five blocks. At stage three, four cells each per block were randomly selected to give twenty cells. At stage four, sixteen (16) farm households were selected from each cell, which gave three hundred and twenty (320) households. Women in the productive age (15-49 years) and under-five children were targeted by the study. In total, 141 boys and 281 girls, aged 0-59 months from 320 households were considered for the study.

\subsection{ANALYTICAL TECHNIQUES AND RESEARCH DESIGN}

Both descriptive and quantitative techniques were used to analyse the data. The choice of both approaches was to ensure that the results are valid and reliable. It is also based on Vetter (2017) that a descriptive research design can answer the questions of who, what, where, when and how. These were the concepts used in the questionnaire in framing the research questions of this study. The descriptive analysis using percentages and frequency analysis were used to describe the sociodemographic characteristics of the variables employed while logit regression model was used to analyze the data and determine the factors related to child malnutrition.

\subsubsection{Welfare Estimates of Children under the Age of Five: Analysis of Anthropometric Measure- ments}

The welfare status of children under the age of five is usually measured using three indices: mass-for-height (wasting) which reflects acute growth disturbances, height-for-age (stunting) which reflects long-term growth faltering and mass-for-age (underweight) which is a combination of both long and short-term effects. Anthropometric data were analyzed to generate welfare indicators of children under the age of five. The study adopted the method of Abera et al. (2017) to convert mass, height, and age of children into height-for-age (HAZ), mass-for-age (MAZ), and mass-for-height (MHZ) in order to assess malnutrition. At the end, the variables for stunting, underweight, and wasting were classified as 1 for stunted and 0 for not stunted, 1 for underweight and 0 for not underweight, and 1 for wasted and 0 for not wasted. On the other hand, the WHO (2006) childgrowth standard was employed for the anthropometric measurements of children.

In line with WHO (2008) and Yalew et al. (2014), the minimum dietary diversity and breastfeeding were used in the study. Seven food groups containing grains, roots and tubers, legumes and nuts, dairy products (milk, yogurt, and cheese), flesh foods (meat, fish, poultry, and liver/organ meats), eggs (vitamin-A rich fruits and vegetables) and other fruits and vegetables were used as good meal frequency.

\subsubsection{Women's bargaining power}

This study made use of the women's decision-making processes within the household as proxy for women's bargaining power. Their ability to make decision about food preparation and consumption (Patel et al., 2007), decision about family asset or investment (Reggio, 2011), decision about gender roles, children education, number of children and health care decision (Allendorf, 2007). This study assumed that women who participate in the 
intra-households decision-making have relative bargaining power. This means that women who partake in family decision-making can be said to have greater bargaining strength than those ones that are excluded.

This study was based on farm households and specifically on married female households. In line with Anderson et al. (2017), this study restricts sample to female's spouses who are living together as husband and wife. The reason for this selection was that when there is no spouse, only the one parent makes decisions. Therefore, female spouses were interviewed taking into consideration that the wife's present husband is the father of the children. This helps to ascertain how they reach important socioeconomic decisions in the family. In order to assess the allocation of household decision-making power, twentytwo (22) questions about household and farm activities were contained in the questionnaire. Using a likert scale ranging from 1 to 10 , respondents were asked to choose the best option that align with their views over a given decision.

Questions included in the questionnaire include the following:

This study adopts questions from Doss (2013), Anderson et al. (2017) and Mengesha and Merkeb (2020). In a scale of 1 to 10 , how is decision-making in the family shared between yourself and your spouse? The decisionmaking power is in the following regards:

(a) Asset ownership

- Land ownership, by plot or parcel, at the individual level?

- $\quad$ Rights associated with the land, by plot/parcel and individual owner?

- Documentation of land ownership, including names on documents?

- Ownership of dwelling?

- Ownership of livestock?

(b) Crop and livestock

- What types of crop to be cultivated on the farm?

- Where to sell crops?

- What types of livestock to be raised on the farm?

- When to sell off the livestock?

- How to spend money raised from the sale of crops?

- How to spend money raised from the sale of livestock?

(c) Decisions about children

- What number of children to have?

- What foods to feed the children?

- Whether to send children to school?

- Type of health practices? (d) Advance decisions

- Whether to buy a new high-yield seed or use the ordinary seeds?

- Whether to buy new farm equipment or use the old tools?

- What types of information or training the household needs?

- Who to attend farm training?

(e) Broad decision-making authority: livelihood versus overall

- Overall decision-making for the household?

- Can you travel to visit your family and friends?

- Can you go to the market alone?

- Can you go to a health clinic for your own health needs?

- Can you take your children to a health clinic alone?

The report of decision-making authority is measured on a scale $(0-10)$ that is assigned to the choice that each spouse choose for themselves and their spouse. The statistics for each of the variables used are summarized in Table 1.

Decision-Making Index (DMI) was used to measure women bargaining power. The whole responses for each respondent (husband and wife) were calculated. However, this study focuses on farm households women bargaining power. The result gotten is the respondent's score on the women decision-making index. The closer the value of the index is to 1 , the higher the women bargaining power. This is as stated below:

$$
\text { Women Decision Making Index }=\text { Number of Cards Allocated to Women } / \text { Totai Number of Cards }
$$

\subsubsection{Estimation model}

In this study, the welfare outcome of children under the age of five is determined by the mother's bargaining power in the family, the child's and women's socioeconomic characteristics, and other household factors. This study focuses on three main welfare outcomes: underweight, stunting and wasting of children under the age of five. The corresponding econometric model is specified as follows:

$$
Y_{i}=\beta_{0}+\beta_{1} P_{i}+\beta_{2} X_{i}+\varepsilon_{i}
$$

Where Yi is a measure of the children welfare outcomes, $\mathrm{Pi}$ is the women's bargaining power, $\mathrm{Xi}$ is the variables of children under the age of five and women's characteristics which are variables that contribute to improvements in child welfare outcomes. 


\section{RESULTS AND DISCUSSION}

\subsection{SOCIOECONOMIC CHARACTERISTICS OF}

\section{WOMEN}

The results of the socio-demographic characteristics

Table 1: Women's socioeconomic characteristics

\begin{tabular}{|c|c|c|c|}
\hline Characteristics & Frequency & Percent & Mean \\
\hline \multicolumn{4}{|l|}{ Age } \\
\hline$\leq 30$ & 176 & 55.00 & \\
\hline $31-40$ & 104 & 32.50 & \\
\hline $41-49$ & 40 & 12.50 & \\
\hline Mean age & & & 29 \\
\hline \multicolumn{4}{|l|}{ Age at marriage } \\
\hline$\leq 20$ & 201 & 62.81 & \\
\hline $21-25$ & 86 & 26.88 & \\
\hline $26-30$ & 18 & 5.63 & \\
\hline$>30$ & 15 & 4.68 & \\
\hline Mean & & & 8 \\
\hline \multicolumn{4}{|l|}{ Number of marriages } \\
\hline Once & 277 & 86.56 & \\
\hline More than once & 43 & 13.44 & \\
\hline \multicolumn{4}{|l|}{ Number of years in marriage } \\
\hline $1-5$ & 67 & 20.94 & \\
\hline $6-10$ & 188 & 58.75 & \\
\hline 11 and above & 65 & 20.31 & 9 \\
\hline \multicolumn{4}{|l|}{ Education } \\
\hline No formal education & 171 & 53.44 & \\
\hline Primary & 94 & 29.38 & \\
\hline Secondary & 44 & 11.75 & \\
\hline Tertiary & 11 & 3.44 & \\
\hline \multicolumn{4}{|l|}{ Body Mass Index $\left(\mathrm{kg} \mathrm{m}^{-2}\right)$} \\
\hline Underweight & 73 & 22.81 & \\
\hline Healthy weight & 148 & 46.25 & \\
\hline Overweight/grade I obesity & 64 & 20.00 & \\
\hline Obese/grade II obesity & 35 & 10.94 & \\
\hline Land ownership & 38 & 11.88 & \\
\hline Livestock ownership & 102 & 31.88 & \\
\hline Access to credit & 77 & 24.06 & \\
\hline \multicolumn{4}{|l|}{ Employment status } \\
\hline Working & 288 & 90.00 & \\
\hline Full housewife & 32 & 10.00 & \\
\hline \multicolumn{4}{|l|}{ Monthly income } \\
\hline Less than 50,000 & 231 & 72.19 & \\
\hline $51,000-\$ 100,000$ & 76 & 23.75 & \\
\hline$\$ 101,000$ and above & 13 & 4.06 & \\
\hline Mean & & & $\$ 41,540$ \\
\hline
\end{tabular}

Source: Author's field survey, 2019 
of the respondents, as presented in Table 1 , show that the dominant age group for women in the study area was less than 30 years, which comprises $55 \%$ of women respondents with a mean age of 29 years. Of 320 respondents, $62.81 \%$ were women under 20 years of age when married and the mean age at marriage was 18 years. This clearly shows that the study concentrated on women in the reproductive age group (15-49 years) and evidence of early marriage is common in rural farm households in Nigeria. About 43 women (13\%) have married more than once and 67 (21\%) women have been married for less than 5 years. Besides, $53.44 \%$ have no formal education. It shows a lower literacy rate among rural women farm households. Overall, nutritional status of $46.25 \%$ of the mothers is normal, that is, they have normal Body Mass Index (BMI) while $28.1 \%$ mothers suffer from lack of energy or thinness and $20 \%$ of women are overweight. In addition, $12 \%$ of the female respondents own land while $32 \%$ own livestock. However, $24 \%$ have access to credit.

\subsection{INFANT AND YOUNG CHILD FEEDING PRACTICES AMONG FARM HOUSEHOLD'S CHILDREN UNDER FIVE YEARS OF AGE}

Table 2 gives the results of the feeding practices among the farm households. While breastfeeding was popular among farm households children (0-23 months), young children's feeding like the minimum dietary diversity was still inadequate and lacking. For example, about $87 \%$ of the children (6-24 months) were inadequately fed with the minimum recommended meal frequency and $77.08 \%$ lack the minimum dietary diversity. $86.12 \%$ of newly born babies do not timely received milk and colostrum. The findings also show that exclusive breastfeeding is done for $0-5$ months (33.535) which is less than the six months recommended by WHO/UNICEF. Children were given other complementary foods, which exposed them to unhealthy feeding and sicknesses.

\subsection{ANTHROPOMETRY RESULTS OF THE WEL-}

\section{FARE OF FARM HOUSEHOLD'S CHILDREN UNDER FIVE YEARS OF AGE}

The WHO (2006) growth standard was employed for anthropometric measurements. As stated under section 3.4.1, the variables for stunting, underweight, and wasting were classified and calculated for farm household's children of 0 to 59 month. As shown in Table 3, the incidence of underweight among children was $32 \%$, and boys $(38.15 \%)$ are more likely to be underweight than girls $(26.43 \%)$. On the other hand, the incidence of stunting was recorded in which about $32 \%$ of the children have stunted growth. The result shows that stunting rises with age, climaxing at slightly above $35 \%$ among children in their second and third year of life. Similar results were found in the previous studies of Yimer (2000); Asfaw and Giotom (2000) in Ethiopia. Severe stunting among farm households with children of age 12-23 months (38.71\%) was also recorded with boys (38.48 \%) more likely to be stunted than girls (30.12\%). This means that male children are more likely to be stunted and underweight than their female counterparts. This finding is consistent with a meta-analysis in sub-Saharan Africa (Wamani et al., 2007), a study in the Northern Ethiopia (Alemayehu et al., 2015), and research in Myanmar (Mya et al., 2019). With underweight and stunting as a chronic malnutrition problem, Omilola (2010) revealed that "stunted children may never regain height lost due to stunting, and most children will never gain the corresponding body mass".

Finally, wasting was found to be the least prevalent malnutrition among farm households' children in the study. It was half (16.2\%) the rate of prevalence in underweight and stunting. However, this value is higher than the prevalence rate of $11 \%$ recorded in Nigeria in 2003 but lower than the figure of $18 \%$ recorded in 2013 (National Population Commission, 2014).

In line with Dabale and Sharma (2014), wasting was higher among boys (16.5\%) than in girls (15.2\%). The highest incidence of wasting was seen among children aged 0-23 months as compared to lowest figure seen among children aged $36-47$ months. This is in line with

Table 2: Feeding practices of farm household's under-five year's old children

\begin{tabular}{lll}
\hline Feeding practices across categories & Frequency & Percent \\
\hline Ever breastfed (0-23 months) & 414 & 98.10 \\
Breastfed exclusively (0-5 months) & 141 & 33.53 \\
Meal frequency (6-24 months) & 369 & 86.61 \\
Not timely receive milk and colostrum within one hour of birth & 363 & 86.12 \\
Not meet the minimum dietary diversity & 326 & 77.08 \\
\hline
\end{tabular}

Source: Author's field survey, 2019 
Table 3: Prevalence of underweight, stunting and wasting in children 0 to 59 months of age

\begin{tabular}{|c|c|c|c|}
\hline \multicolumn{4}{|c|}{ Prevalence of overall, moderate and severe underweight status (Mass-for-Age Z-score) in children 0 to 59 months of age } \\
\hline Characteristics & $\%$ Prevalence of underweight & $\%$ Prevalence of moderate underweight & $\begin{array}{l}\% \text { Prevalence of severe under- } \\
\text { weight }\end{array}$ \\
\hline Overall & 32.00 & 27.65 & 4.35 \\
\hline \multicolumn{4}{|l|}{ Sex } \\
\hline Boy & 38.15 & 31.74 & 6.41 \\
\hline Girl & 26.43 & 21.01 & 5.42 \\
\hline \multicolumn{4}{|l|}{ Age } \\
\hline 0-5 Months & 28.17 & 18.62 & 9.55 \\
\hline 6-11 Months & 39.26 & 32.96 & 6.30 \\
\hline 12-23 Months & 36.83 & 29.27 & 7.56 \\
\hline 24-35 Months & 30.11 & 24.50 & 5.61 \\
\hline 36-47 Months & 32.54 & 26.81 & 5.73 \\
\hline 48-59 Months & 29.62 & 25.18 & 4.44 \\
\hline
\end{tabular}

Prevalence of overall, moderate and severe stunting status (Height-for-Age) in children 0 to 59 months of age

\begin{tabular}{llll}
\hline Characteristics & \% Prevalence of stunting & \% Prevalence of moderate stunting & \% Prevalence of severe stunting \\
\hline Overall & 31.82 & 23.76 & 8.06 \\
Sex & & & \\
Boy & 38.48 & 29.78 & 8.70 \\
Girl & 30.12 & 25.88 & 4.24 \\
Age & & & 5.24 \\
0-5 Months & 30.11 & 24.87 & 3.83 \\
6-11 Months & 32.65 & 28.82 & 8.86 \\
12-23 Months & 38.71 & 29.85 & 4.45 \\
24-35 Months & 35.27 & 30.82 & 4.54 \\
36-47 Months & 33.54 & 29.09 & 7.94 \\
48-59 Months & 32.03 & 24.09 &
\end{tabular}

Prevalence of wasting (Mass-for -Height) in children 0 to 59 months of age

\begin{tabular}{llll}
\hline Characteristics & \% Prevalence of wasting & \% Prevalence of moderate wasting & \% Prevalence of severe wasting \\
\hline Overall & 16.20 & 10.30 & 5.72 \\
Sex & & & 5.72 \\
Boy & 16.50 & 10.30 & 5.20 \\
Girl & 15.20 & 10.00 & \\
Age & & & 5.20 \\
0-5 Months & 16.60 & 11.40 & 5.10 \\
6-11 Months & 16.70 & 11.60 & 6.30 \\
12-23 Months & 16.40 & 10.10 & 4.60 \\
24-35 Months & 15.80 & 11.20 & 4.20 \\
36-47 Months & 15.10 & 10.90 & 5.05 \\
48-59 Months & 15.30 & 10.25 & \\
\hline
\end{tabular}

Source: Author's field survey, 2019.

Akombi et al. (2017), which posited that the incidence of 
Table 4: Extent of wasting and stunting in under five year old children

\begin{tabular}{lllll}
\hline & No stunting & Moderate stunting & Severe stunting & Total \\
\hline No wasting & 62.44 & 17.38 & 4.16 & 83.98 \\
Moderate wasting & 4.12 & 3.33 & 2.85 & 10.30 \\
Severe wasting & 1.62 & 3.05 & 1.05 & 5.72 \\
Total & 68.18 & 23.76 & 8.06 & 100.00 \\
\hline
\end{tabular}

Source: Author's field survey, 2019

\subsection{EXTENT OF (DUAL MALNUTRITION DEFI- CITS) WASTING AND STUNTING IN CHIL- DREN UNDER FIVE YEARS OF AGE}

Table 4 shows the combined burden of stunting and wasting of children less than five year of age. Children growing up healthy are $62.44 \%$, implying that one - third of farm household's children less than five years of age in the study area still experiences nutrition deficiency. Children suffering from the simultaneous occurrence of stunting and wasting are $3.33 \%$ while $1.05 \%$ are undergoing severe stunting and wasting together. This might not be unconnected with the environmental condition and harsh deprivation of the farm household's children, especially in the rural area. As a policy recommendation, it is therefore, advisable that good nutrition be introduced to the children and treatment for malnutrition illnesses be carried out among the farm household's children in the study area. This recommendation is in line with Babatunde et al. (2011) that suggested that government should enact food policy that will increase daily per capita household calorie supply especially in the rural area.

\subsection{THE PATTERN OF WOMEN BARGAINING POWER}

Table 5 shows that $63.33 \%$ of women in the study area have low bargaining power, while $26.25 \%$ have moderate bargaining power and $10.42 \%$ have high bargaining power. This implies that the men were adequate in more indicators than the women; the women were ad- equate in more indicators than the man in $10 \%$ of households; and the man and the women are equally adequate in $26 \%$ of households. On average, the male respondents are adequate in $63 \%$ more indicators (approximately two indicators) than the female respondent in the same household. Therefore, women lack control over important decisions in their households.

\subsubsection{Effects of women's bargaining power on farm household's welfare of the children less than five years of age}

Table 6 presents the results of the logit regression model. Women farm households' involvement in productive activities have a positive effect on their child's welfare outcomes. When they are employed or involved in other income generating activities, there is a lower likelihood of their being underweight, stunted and wasted. Belch and Willis (2002) revealed that women (farm households) with more financial resources wield more power in household decision-making and have stronger bargaining power in the family. In addition, Getahun and Villanger (2017) also revealed that wives that are employed have high bargaining power, as they are able to contribute to household expenditures and this improves their participation in the intra-household decision-making. Women's incomes provide them with the bargaining power and control over major decision like schooling and consumption expenditures (Doss, 2013). It explains how they can live on during family challenges or marriage break-up, and reflects how the children can be well taken care of without the man. This means that higher

Table 5: Pattern of women bargaining power

Level of bargaining power

Low bargaining power (the decision is taken mainly by men) $(\mathrm{DM} 1=0.33$ )

Moderate bargaining power (the decision is shared) $(\mathrm{DMI}=0.34-0.66)$

High bargaining power (the decision is taken mainly by women) (DMI0.67)

Total

$\begin{array}{ll}\text { Frequency } & \text { Percentage } \\ 203 & 63.33 \\ 84 & 26.25 \\ 33 & 10.42 \\ 320 & 100\end{array}$

Source: Field survey, 2019. 
Table 6: Logit regression results of the effects of farm households women's bargaining power on welfare of under-five years old children

\begin{tabular}{|c|c|c|c|c|c|c|}
\hline \multirow[b]{2}{*}{ Variables } & \multicolumn{2}{|c|}{ Underweight } & \multicolumn{2}{|l|}{ Stunting } & \multicolumn{2}{|l|}{ Wasting } \\
\hline & Coefficient & t-value & Coefficient & t-value & Coefficient & t-value \\
\hline \multicolumn{7}{|l|}{ Children's characteristics } \\
\hline Sex (male dummy) & $1.09^{\star}$ & 1.95 & $0.73^{* *}$ & 2.28 & 0.73 & 1.28 \\
\hline Age (years) & $2.52^{\star *}$ & 2.04 & $1.98^{\star *}$ & 2.33 & $-1.98^{\star *}$ & -2.33 \\
\hline Birth order & $11.01^{\star * *}$ & 3.43 & $5.82^{\star *}$ & 2.19 & $5.82^{\star *}$ & 2.19 \\
\hline Birth mass (kg) & $-0.33^{\star \star *}$ & -3.82 & $-0.33^{\star * \star}$ & -4.45 & $-0.12^{* * *}$ & -5.12 \\
\hline Multiple birth & $1.21^{*}$ & 1.89 & -0.42 & -1.48 & -0.42 & -1.42 \\
\hline \multicolumn{7}{|l|}{ Mother's characteristics } \\
\hline Mother's BMI (overweight dummy) & $-0.22^{\star * *}$ & -2.62 & $-0.06^{\star *}$ & -2.13 & $-0.06^{\star \star}$ & -2.13 \\
\hline Maternal stature (short dummy) & $2.35^{\star *}$ & 2.28 & $1.13^{* * *}$ & 2.94 & -1.13 & -1.02 \\
\hline Age at first marriage & $-3.50^{* * *}$ & 6.12 & $-2.14^{\star *}$ & 2.31 & 1.11 & 0.98 \\
\hline Educational attainment (number of years of schooling) & $-0.18^{\star * \star}$ & -5.11 & $-0.23^{\star *}$ & -2.02 & $-0.34^{* * *}$ & 4.19 \\
\hline Employment status (working dummy) & $-0.72^{\star}$ & -1.91 & $-0.35^{\star *}$ & -2.31 & $-0.34^{\star * \star}$ & -3.32 \\
\hline mother's first child (male dummy) & 0.09 & 0.83 & 0.09 & 0.92 & 0.09 & 0.92 \\
\hline Income & 0.16 & 1.38 & 0.13 & 1.44 & 0.13 & 1.46 \\
\hline Bargaining power & $-7.68^{\star * \star}$ & -3.77 & $-5.23^{\star \star *}$ & -3.25 & $-5.21^{\star * *}$ & -3.25 \\
\hline Frequency of antenatal visit & 0.02 & 0.14 & $-0.17^{\star \star}$ & -2.14 & -0.17 & -1.14 \\
\hline Constant & $0.04^{* *}$ & 2.02 & $0.03^{\star * *}$ & 5.12 & $0.01^{\star}$ & 1.99 \\
\hline \multicolumn{7}{|l|}{ LR $C h i^{2}=412.04$} \\
\hline \multicolumn{7}{|l|}{ Prob $>C h i^{2}=0.0000$} \\
\hline \multicolumn{7}{|l|}{ Pseudo $\mathrm{R}^{2}=0.2514$} \\
\hline Log likelihood $=-1664.24$ & & & & & & \\
\hline
\end{tabular}

Note: ${ }^{* * *},{ }^{* *}, \&^{*}$ implies significant at $\mathrm{p}<0.001, \mathrm{p}<0.05, \& \mathrm{p}<0.01$ respectively.

incomes or earnings increase women's bargaining power and ability to participate in intra-households decisionmaking especially among the rural farmers.

Age also plays a significant role in women's empowerment. McElroy (1990) contends that "spousal age measures how well each family member can do in the marriage or remarriage market". Therefore, newer wives may have more bargaining power during negotiations. Equally, older wives may have greater bargaining power and influence on decision-making that positively contribute to the welfare of their children (Chari et al., 2017) and increase the nutritional status of their children. This is because older wives would have more influence on their children's welfare, leading to a higher bargaining power.

The coefficient on the variable for bargaining power that captures mother participation in household's decision-making was significant at the $1 \%$ and positively related to child's health outcomes. This means that the higher the women's bargaining power, the lower the like- lihood of the under-five children in the farm household to be underweight, stunted and wasted. Therefore, women with greater decision-making power in the household, especially concerning large purchases, are more empowered and associated with having children with better nutrition, which will translate to better height-for-age, mass-for-age and mass-for-height ratios.

\section{CONCLUSION}

This paper examines whether greater women's household bargaining power is associated with the improvement in children's welfare in Ogun State, Nigeria. It examines the relationship between farm households women's intra-households decision-making power and child's welfare outcomes. Using cross-sectional farm household data from Abeokuta-Ogun State, the findings revealed that an increase in mother's bargaining power can benefit the child and increase his or her welfare out- 
comes. The study shows that women with greater intrahousehold decision-making power are associated with having children with better height-for-age, weight-forage, and weight-for-height ratios.

Women farm households' involvement in productive activities have a positive effect on their child's welfare outcomes. The broader social economic implication is that when women are employed or involved in other income generating activities, there is a lower likelihood of their children being underweight, stunted and wasted. This means that wives that are employed have high bargaining power, as they are able to contribute to household expenditures and this improves their participation in the intra-household decision-making (Getahun and Villanger, 2017). Women's incomes provide them with the bargaining power and control over major decision like schooling and consumption expenditures.

This study is however, limited in scope as it was carried out in Southwest part of the country. The researchers believe that further studies (future researchers) could scale-up the scope and focus on other part of the country particularly those that fall outside of the Southwest region, as the finding is very relevant and germane for developing countries and particularly in Nigeria where gender inequality persists when it comes to intra-household decision-making in the family. The paper deals with relevant social issue and contributes to existing literature on women's intra-households bargaining power using the farm households as a case study. There was an established relationship between women's empowerment and child welfare. Overall, it can be concluded that women's empowerment and their enhancement in intra-households decision-making are crucial elements to achieving better children welfare and sustainable development. Therefore, policies and programmes should be focused on increasing women's farm households' status and empowerment, as this will lead to more investment in their children's education, health, and overall welfare.

\section{REFERENCES}

Abera, L., Dejene, T., \& Laelago, T. (2017). Prevalence of malnutrition and associated factors in children aged 6-59 months among rural dwellers of damot gale district, south Ethiopia: community based cross sectional study. International journal for equity in health, 16(1), 111. https://doi.org/10.1186/ s12939-017-0608-9

Akombi, B. J., Agho, K. E., Merom, D., Hall, J. J., \& Renzaho, A. M. (2017). Multilevel analysis of factors associated with wasting and underweight among children under-five years in Nigeria. Nutrients, 9(1), 44. https://doi.org/10.3390/ nu9010044

Alemayehu, M., Tinsae, F., Haileslassie, K., Seid, O., Gebregzi- abher, G., \& Yebyo, H. (2015). Undernutrition status and associated factors in under-5 children, in Tigray, Northern Ethiopia. Nutrition, 31(7-8), 964-970. https://doi. org/10.1016/j.nut.2015.01.013

Allendorf, K. (2007). Do women's land rights promote empowerment and child health in Nepal?. World development, 35(11), 1975-1988. https://doi.org/10.1016/j.worlddev.2006.12.005

Anderson, C. L., Reynolds, T. W., \& Gugerty, M. K. (2017). Husband and wife perspectives on farm household decisionmaking authority and evidence on intra-household accord in rural Tanzania. World development, 90, 169-183. https:// doi.org/10.1016/j.worlddev.2016.09.005

Angel-Urdinola, D., \& Wodon, Q. (2010). Income generation and intra-household decision making: A gender analysis for Nigeria. Gender disparities in Africa's labor market, 381.

Asfaw, S. T., \& Giotom, L. (2000). Malnutrition and enteric parasitoses among under-five children in Aynalem Village, Tigray. Ethiopian Journal of Health Development, 14(1), 6775. https://doi.org/10.4314/ejhd.v14i1.9931

Babatunde, R. O., Olagunju, F. I., Fakayode, S. B., \& Sola-Ojo, F. E. (2011). Prevalence and determinants of malnutrition among under-five children of farming households in Kwara State, Nigeria. Journal of Agricultural Science, 3(3), 173-181. https://doi.org/10.5539/jas.v3n3p173

Behrman, J. R., \& Skoufias, E. (2006). Mitigating myths about policy effectiveness: evaluation of Mexico's antipoverty and human resource investment program. The ANNALS of the American Academy of Political and Social Science, 606(1), 244-275. https://doi.org/10.1177/0002716206288956

Belch, M. A., \& Willis, L. A. (2002). Family decision at the turn of the century: Has the changing structure of households impacted the family decision-making process?. Journal of Consumer Behaviour: An International Research Review, 2(2), 111-124. https://doi.org/10.1002/cb.94

Chari, A. V., Heath, R., Maertens, A., \& Fatima, F. (2017). The causal effect of maternal age at marriage on child wellbeing: Evidence from India. Journal of Development Economics, 127, 42-55. https://doi.org/10.1016/j.jdeveco.2017.02.002

Chen, Y., \& Li, H. (2009). Mother's education and child health: Is there a nurturing effect? Journal of health economics, 28(2), 413-426. https://doi.org/10.1016/j.jhealeco.2008.10.005

Dabale, G. A., \& Sharma, M. K. (2014). Determinants of wasting among under-five children in Ethiopia: (a multilevel logistic regression model approach). International Journal of Statistics in Medical Research, 3(4), 368-377. https://doi. org/10.6000/1929-6029.2014.03.04.5

De Onis, M., \& Blössner, M. (2003). The World Health Organization global database on child growth and malnutrition: methodology and applications. International journal of epidemiology, 32(4), 518-526. https://doi.org/10.1093/ije/ dyg099

Doepke, M., \& Tertilt, M. (2011). Does female empowerment promote economic development?. The World Bank. https:// doi.org/10.1596/1813-9450-5714

Doss, C. (2013). Intra household bargaining and resource allocation in developing countries. The World Bank Research 
Observer, 28(1), 52-78. https://doi.org/10.1093/wbro/ lkt001

Duflo, E. (2000). Child health and household resources in South Africa: evidence from the old age pension program. American Economic Review, 90(2), 393-398. https:// doi.org/10.1257/aer.90.2.393

Fasina, F., Oni, G., Azuh, D., \& Oduaran, A. (2020). Impact of mothers' socio-demographic factors and antenatal clinic attendance on neonatal mortality in Nigeria. Cogent Social Sciences, 6(1), 1747328. https://doi.org/10.1080/23311886. 2020.1747328

Fink, G., Sudfeld, C. R., Danaei, G., Ezzati, M., \& Fawzi, W. W. (2014). Scaling-up access to family planning may improve linear growth and child development in low and middle income countries. PLoS One, 9(7), e102391. https://doi. org/10.1371/journal.pone.0102391

Getahun, T. D., \& Villanger, E. (2018). Labour-intensive jobs for women and development: Intra-household welfare effects and its transmission channels. The Journal of Development Studies, 54(7), 1232-1252. https://doi.org/10.1080/0022038 8.2017 .1327661

Gokhale, M. K., Kanade, A. N., Rao, S., Kelkar, R. S., Joshi, S. B., \& Girigosavi, S. T. (2004). Female literacy: the multifactorial influence on child health in India. Ecology of food and nutrition, 43(4), 257-278. https://doi. org/10.1080/03670240490454688

Grown, C., Gupta, G. R., \& Kes, A. (2005). Taking action: achieving gender equality and empowering women. Earthscan.

Gummerson, E., \& Schneider, D. (2013). Eat, drink, man, woman: Gender, income share and household expenditure in South Africa. Social forces, 91(3), 813-836. https://doi. org/10.1093/sf/sos173

Guvuriro, S., \& Booysen, F. (2019). Economic bargaining power and financial decision-making between married and cohabitant women in South Africa. Development Southern Africa, 36(4), 504-518.

Herrador, Z., Sordo, L., Gadisa, E., Moreno, J., Nieto, J., Benito, A., \& Custodio, E. (2014). Cross-sectional study of malnutrition and associated factors among school aged children in rural and urban settings of Fogera and Libo Kemkem districts, Ethiopia. PloS one, 9(9), e105880. https:/doi. org/10.1371/journal.pone.0105880

Khara, T., Mwangome, M., Ngari, M., \& Dolan, C. (2018). Children concurrently wasted and stunted: A meta-analysis of prevalence data of children 6-59 months from 84 countries. Maternal \& child nutrition, 14(2), e12516. https://doi. org/10.1111/mcn.12516

Liu, L., Oza, S., Hogan, D., Perin, J., Rudan, I., Lawn, J. E., \& Black, R. E. (2015). Global, regional, and national causes of child mortality in 2000-13, with projections to inform post-2015 priorities: an updated systematic analysis. The Lancet, 385(9966), 430-440. https://doi.org/10.1016/S01406736(14)61698-6

Malhotra, A., \& Schuler, S. R. (2005). Women's empowerment as a variable in international development. Measuring empowerment: Cross-disciplinary perspectives, 1(1), 71-88.

Martínez A, C. (2013). Intra household allocation and bargaining power: Evidence from Chile. Economic Develop- ment and Cultural Change, 61(3), 577-605. https://doi. org/10.1086/669260

McElroy, M. B. (1990). The empirical content of Nash-bargained household behavior. Journal of human resources, 559-583. https://doi.org/10.2307/145667

Mengesha, D. K., \& Merkeb, Y. (2020). Prevalence of malnutrition and associated risk factors among children under five years of age in Amhara region, Ethiopia: Evidence from 2016 Ethiopian demographic and health survey. https://doi. org/10.21203/rs.3.rs-54072/v1

Mya, K. S., Kyaw, A. T., \& Tun, T. (2019). Feeding practices and nutritional status of children age 6-23 months in Myanmar: A secondary analysis of the 2015-16 Demographic and Health Survey. PloS one, 14(1), e0209044. https://doi. org/10.1371/journal.pone.0209044

National Population Commission (NPC) [Nigeria] and ICF International. (2014). Nigeria Demographic and Health Survey 2013. Abuja, Nigeria, and Rockville, Maryland, USA: NPC and ICF International.

National Population Commission (NPC) [Nigeria] and ICF Macro. (2009). Nigeria Demographic and Health Survey 2008. Abuja, Nigeria: National Population Commission and ICF Macro.

National Population Commission (NPC) [Nigeria], National Malaria Control Programme (NMCP) [Nigeria], and ICF International (2012). Nigeria Malaria Indicator Survey 2010. Abuja, Nigeria: NPC, NMCP, and ICF International.

Ogunlesi, T. A., \& Ogunlesi, F. B. (2012). Family socio-demographic factors and maternal obstetric factors influencing appropriate health-care seeking behaviours for newborn jaundice in Sagamu, Nigeria. Maternal and child health journal, 16(3), 677-684. https://doi.org/10.1007/s10995011-0765-1

Omilola, B. (2010). Patterns and trends of child and maternal nutrition inequalities in Nigeria (No. 968). International Food Policy Research Institute (IFPRI).

Patel, A., Leonard, W., Reyes-García, V., McDade, T., Huanca, T., Tanner, S., \& Vadez, V. (2007). Parental preference, bargaining power, and child nutritional status: Evidence from the Bolivian Amazon. Tsimane'Amazonian Panel Study Working Paper, 31.

Pelletier, D. L., \& Frongillo, E. A. (2003). Changes in child survival are strongly associated with changes in malnutrition in developing countries. The Journal of nutrition, 133(1), 107-119. https://doi.org/10.1093/jn/133.1.107

Pratley, P. (2016). Associations between quantitative measures of women's empowerment and access to care and health status for mothers and their children: a systematic review of evidence from the developing world. Social Science \& Medicine, 169, 119-131. https://doi.org/10.1016/j.socscimed.2016.08.001

Reggio, I. (2011). The influence of the mother's power on her child's labor in Mexico. Journal of development economics, 96(1), 95-105. https://doi.org/10.1016/j.jdeveco.2010.07.002

Richards, E., Theobald, S., George, A., Kim, J. C., Rudert, C., Jehan, K., \& Tolhurst, R. (2013). Going beyond the surface: gendered intra-household bargaining as a social determinant of child health and nutrition in low and middle in- 
come countries. Social science \& medicine, 95, 24-33. https://doi.org/10.1016/j.socscimed.2012.06.015

Saaka, S. (2018). Women's intra-household bargaining power and child welfare outcomes: evidence from Sub-Saharan Africa (Doctoral dissertation, University of Sussex).

The United Nations Children's Fund. World Health Organization. World Bank. UNICEF (2015). WHO-The World Bank Child Malnutrition Database: Estimates for 2015 and Launch of Interactive Data Dashboards. New York: The United Nations Children's Fund; 2015.

Tolhurst, R., Amekudzi, Y. P., Nyonator, F. K., Squire, S. B., \& Theobald, S. (2008). "He will ask why the child gets sick so often": The gendered dynamics of intra-household bargaining over healthcare for children with fever in the Volta Region of Ghana. Social science \& medicine, 66(5), 11061117.v

UNICEF (2016). The state of the World's children (2016). A fair chance for every child, United Nations, New York, https:// doi.org/10.18356/4fb40cfa-en.

UNICEF/WHO/World Bank Group (2017). Joint Child Malnutrition Estimates 2017 Edition, UNICEF/WHO/World Bank Group, Geneva, Switzerland, 2017.

UNICEF/WHO/World Bank/UN (2013). Levels and Trends in Child Mortality. USA; 2013.

Vetter, T. R. (2017). Descriptive Statistics: Reporting the Answers to the 5 Basic Questions of Who, What, Why, When, Where, and a Sixth, So What? Anesthesia \& Analgesia, 125(5), 1797-1802. https://doi.org/10.1213/ ANE.0000000000002471

Wang, S. Y. (2014). Property rights and intra-household bargaining. Journal of Development Economics, 107, 192-201. https://doi.org/10.3386/w19427

Wamani, H., Åstrøm, A. N., Peterson, S., Tumwine, J. K., \& Tylleskär, T. (2007). Boys are more stunted than girls in
sub-Saharan Africa: a meta-analysis of 16 demographic and health surveys. BMC pediatrics, $7(1), 17$. https://doi. org/10.1186/1471-2431-7-17

World Bank (2011). "World Development Report 2012: Gender Equality and Development" The International Bank for Reconstruction and Development: Washington, D.C., 2011.

World Health Organization. (2006). WHO child growth standards: length/height-for-age, weight-for-age, weight-for-length, weight-for-height and body mass index-for-age: methods and development. World Health Organization.

World Health Organization. (2008). Indicators for assessing infant and young child feeding practices: part 1: definitions: conclusions of a consensus meeting held 6-8 November 2007 in Washington DC, USA. World Health Organization.

World Health Organization. (2016). The double burden of malnutrition: policy brief (No. WHO/NMH/NHD/17.3). World Health Organization.

Yalew, B. M., Amsalu, F., \& Bikes, D. (2014). Prevalence and factors associated with stunting, underweight and wasting: A community based cross sectional study among children age 6-59 months at Lalibela Town, Northern Ethiopia. J Nutr Disorders Ther, 4(147), 2161-0509. https://doi. org/10.4172/2161-0509.1000147

Yimer, G. (2000). Malnutrition among children in Southern Ethiopia: Levels and risk factors. Ethiopian journal of health development, 14(3). https://doi.org/10.4314/ejhd. v14i3.9901

Yusof, S. A., \& Duasa, J. (2010). Household decision-making and expenditure patterns of married men and women in Malaysia. Journal of family and economic issues, 31(3), 371381. https://doi.org/10.1007/s10834-010-9200-9

Zuckerman, E. (2007). Critique: gender equality as smart economics: World Bank Group gender action plan (fiscal years 2007-10). Washington DC: Gender Action. 